\title{
Two antihyperglycaemic compounds from Globimetula braunii (Engl.) Van Tiegh (Loranthaceae)
}

\author{
Ayoola Marcus Durojaye ${ }^{1, *}$, Oriola Ayodeji Oluwabunmi ${ }^{2}$, Faloye Kolade Olatubosun ${ }^{3}$ and Aladesanmi \\ Adetunji Joseph ${ }^{1}$
}

${ }^{1}$ Department of Pharmacognosy, Obafemi Awolowo University, Ile-Ife, Osun State, Nigeria.

${ }^{2}$ Drug Research and Production Unit, Obafemi Awolowo University, Ile-Ife, Osun State, Nigeria.

${ }^{3}$ Department of Chemistry, Obafemi Awolowo University, Ile-Ife, Osun State, Nigeria.

Publication history: Received on 13 March 2020; revised on 25 March 2020; accepted on 02 April 2020

Article DOI: https://doi.org/10.30574/gscbps.2020.11.1.0066

\begin{abstract}
Large numbers of medicinal plants are constantly being screened for possible pharmacological values, especially for chronic diseases such as diabetes, with the view of discovering new compounds that may serve as templates for synthesis of more active/less toxic drugs. Therefore, the antihyperglycaemic activity of the leaf of Globimetula braunii with antidiabetic ethnomedical usage in Nigeria was investigated is this study to justify this folkloric claim. The median lethal dose, $\mathrm{LD}_{50}$ of the ethanol leaf extract of $G$. braunii was determined using Lorke's method and its antihyperglycaemic effect at 100, 200 and $400 \mathrm{mg} / \mathrm{kg}$ was evaluated using glucose-induced hyperglycaemic rats while glibenclamide $(5 \mathrm{mg} / \mathrm{kg}$ ) and $1 \%$ Tween 80 in normal saline served as positive and negative controls, respectively. Anti-hyperglycaemic activity-directed purification of the extract of the plant in glucose-loaded rats, led to the isolation and characterisation of phyllanthone and methyl 2, 6-dihydroxy-4-methoxybenzoate from the dichloromethane partitioned fraction. The findings showed that the LD 50 of the ethanol leaf extract of $G$. braunii was greater than 5,000 $\mathrm{mg} / \mathrm{kg}$ while its $100 \mathrm{mg} / \mathrm{kg}$ was the most active dose with comparable activity ( $>0.05$ ) to the standard drug, glibenclamide. The dichloromethane and aqueous partitioned fractions of the extract were the most promising fractions. Chromatographic separations of the dichloromethane fraction yielded phyllanthone, and methyl 2, 6dihydroxy-4-methoxybenzoate that elicited comparable activity to glibenclamide (5 mg/kg) at 10 and $20 \mathrm{mg} / \mathrm{kg}$ at all time-points. The study justified the antidiabetic folkloric use of $G$. braunii leaf and confirmed phyllanthone and methyl 2,6-dihydroxy-4-methoxybenzoate as two of its antihyperglycaemic constituents.
\end{abstract}

Keywords: Globimetula braunii; Antihyperglycaemic activity; Phyllanthone; methyl 2,6-dihydroxy-4methoxybenzoate

\section{Introduction}

Medicinal plants are plants which, in one or more of their organs, contain substances that can be used for therapeutic purposes or which are precursors for the synthesis of useful drugs [1]. They have the ability to synthesis a wide variety of chemical compounds that possess pharmacological properties, and defend against attack from predators such as insects, fungi and herbivores [2,3]. These compounds also known as phytochemicals, have been found to exert their effects on the human body through mechanisms that are similar to those already established in conventional drugs revealing that herbal medicines may be as effective as the latter [2, 4]. About $25 \%$ of the drugs prescribed worldwide come from medicinal plants and out of the 252 drugs considered as basic and essential by the World Health Organisation, $11 \%$ are exclusively of plant origin and a significant number are synthetic drugs obtained from natural

${ }^{*}$ Corresponding author: Ayoola Marcus Durojaye

Copyright (C) 2020 Author(s) retain the copyright of this article. This article is published under the terms of the Creative Commons Attribution Liscense 4.0. 
precursors [5]. The plant kingdom is believed to hold many new drug templates; hence, the continued investigation into ethno-medicinal plants [6].

Globimetula braunii, commonly known as African Mistletoe and called, "Àfòmóonísànó" among the Yoruba tribe in Nigeria is a hemi-parasitic shrub that grows on dicotyledonous trees such as Albizzialebbeck, Terminalia mantaly, Terminalia catappa, Khaya senegalensis, Citrus grandis, Cola acuminata and Theobroma cacao [7]. It attaches itself to the host by modified roots otherwise known as "haustorium" [8]. Ethno medicinally, its various parts (leaves, stems, berries and flowers) are majorly used in herbal medicine for the treatment of headache, rheumatic pain, hypertension, ulcer, pulmonary problems, and cancer $[8,9,10]$. It has been reported for various biological activities including lipid lowering [10], antioxidant [11], antibacterial [7], laxative [12] oxytocic [13] hypoglycaemic [14], anticonvulsant property [15], anti-inflammatory and analgesic activities [16]. Two lactones namely 6-[2-hydroxy-4-(4-hydroxyphenyl)butyl]-5,6dihydropyran-2-one and 2-[(4-hydroxyphenyl)ethyl-2,6-dioxabicyclo-1]-nonan-3-one and five flavonoids namely, quercetin, catechin, qercitrin, rutin and avicularin have been isolated from its leaf [17]. This study was carried out to scientifically justify the antidiabetic ethnomedical usage of the leaf of Globimetula braunii in Nigeria.

\section{Methods}

\subsection{Chemicals, equipment and instrumentation}

Finetest $^{\mathrm{TM}}$ Glucometer (model IGM-0005A) with Finetest ${ }^{\mathrm{TM}}$ strips, Infopia Co.Ltd., Korea), column chromatographic (dimension: $80 \times 4 \mathrm{~cm}$ ) apparatuses were used. Others were aluminium plates, thin-layer chromatographic, silica gel $\left(60 \mathrm{~F}_{254}, 0.25 \mathrm{~mm}\right)$ and silica gel (80-400 mesh, Merck \& Co., Inc., U.S.A.). Nuclear magnetic resonance (NMR) spectra $(300 \mathrm{MHz})$ were obtained with Bruker AMX 300 spectrometer. All solvents used were of analytical grade.

\subsection{Animals}

Male and female healthy Wistar albino rats, average weight of $150 \mathrm{~g}$ and bred at $27 \pm 3^{\circ} \mathrm{C}, 65 \%$ relative humidity, $12 \mathrm{~h}$ day-night and housed in different cages in the animal house, Department of Pharmacology, Faculty of Pharmacy, O.A.U., Ile-Ife, Nigeria, were used for the study. They were fed on a standard pellet diet from 'Bendel Feeds', Benin, Nigeria, with water given as required. Groups of five rats were fasted for $24 \mathrm{~h}$ before administration of either glucose, extract, fractions, drugs or vehicle. All animal experiments conformed to the Guide for the Care and Use of Laboratory Animals published by the National Academies Press [18].

\subsection{Plant material and Extraction}

The leaf of Globimetula braunii was collected on Leucena leucocephala (Fabaceae) at Obafemi Awolowo University, IleIfe, Osun State and authenticated at the Ife Herbarium, Department of Botany, Obafemi Awolowo University, Ile-Ife, Nigeria, with the Voucher number IFE 17229. It was then air-dried and milled into powder. A $1.5 \mathrm{~kg}$ of the leaf was extracted with 7.5 Litres of $80 \%$ ethanol by maceration at room temperature. It was then filtered and concentrated using rotary evaporator to afford a yield of $105 \mathrm{~g}$ of ethanol extract.

\subsection{Partitioning of the extract}

The ethanol leaf extract ( $100 \mathrm{~g}$ ), coded, A was suspended in $200 \mathrm{~mL}$ of distilled water and successively partitioned with dichloromethane $(500 \mathrm{~mL} \times 3)$, ethylacetate $(500 \mathrm{~mL} \times 5)$ and $n$-butanol (200 $\mathrm{mL} \times 2$ ). Each partitioned fraction was concentrated to dryness at $50^{\circ} \mathrm{C}$ using rotary evaporator to give, dichloromethane $\left(\mathbf{B}_{1}, 23.7 \mathrm{~g}\right)$, ethylacetate $\left(\mathbf{B}_{2}, 17.4 \mathrm{~g}\right)$, $n$-butanol ( $\left.\mathbf{B}_{3}, 24.0 \mathrm{~g}\right)$ and aqueous $(\mathbf{B 4}, 26.5 \mathrm{~g})$ partition fractions.

\subsection{Acute toxicity study of the extract}

The biological safety of Globimetula braunii was evaluated by determining the $\mathrm{LD}_{50}$ of its ethanol extract, using the 1983 Lorke's method [19]. Animals weighing between 120-150 g were fasted overnight before doses of $10-5,000 \mathrm{mg} / \mathrm{kg}$ of the extract were administered orally. The study was carried out in two phases. Phase 1 of the study involved nine (9) rats that were divided into 3 groups of 3 rats each and were given the extract, with each group receiving 10, 100 and $1000 \mathrm{mg} / \mathrm{kg}$, respectively. These animals were observed for mortality and or toxicity signs within each group over a 24hour period. Due to the results obtained from phase 1, phase 2 study was carried out, using eight (8) rats that were divided into 4 groups of 2 rats each, which were given 1000,1600, 2900 and $5000 \mathrm{mg} / \mathrm{kg}$ of the extract, respectively. The animals were also observed for mortality and/or toxicity signs for 24 hours. The LD 50 was calculated as the geometric mean of the dose that resulted in $100 \%$ lethality and that which caused no lethality at all [19].

$\mathrm{LD}_{50}=\sqrt{\mathrm{D}_{0}} \times \mathrm{D}_{1}$ 
Where, $\mathrm{D}_{0}=$ highest dose that gave no mortality: $\mathrm{D}_{1}=$ lowest dose that produced mortality.

\subsection{Antihyperglycaemic assay of the extract fractions}

The antihyperglycaemic assay of the extract, $\mathbf{A}$ and its partition fractions, $\mathbf{B}_{\mathbf{1}}-\mathbf{B}_{\mathbf{4}}$ were carried out in glucose-induced hyperglycaemic normal rats as described by Adebajo, Ayoola and their co-workers [20-23].

\subsection{Isolation of Compounds from the Active DCM Fraction}

A $20.0 \mathrm{~g}$ of active dichloromethane partition fraction $\left(\mathbf{B}_{\mathbf{1}}\right)$ was adsorbed on silica gel and subjected to column chromatography using gradient solvent systems of increasing polarity comprising of $n$-Hex, DCM, EtOAc and MeOH. A total of four bulked column fractions based on TLC analysis were obtained and coded, $\mathbf{C}_{\mathbf{1}}-\mathbf{C}_{\mathbf{4}}$. Column fractions $\mathbf{C}_{\mathbf{1}}$ and $\mathbf{C}_{2}$ formed solid deposits within $12 \mathrm{hrs}$ of standing. Therefore, $\mathbf{C}_{\mathbf{1}}$ was washed with $20 \% \mathrm{DCM}$ in $\mathrm{MeOH}$, which yielded a whitish amorphous powder, coded, $\mathbf{G}_{\mathbf{1}}(30 \mathrm{mg})$. Also, $\mathbf{C}_{2}$ was washed with DCM (100\%) which yielded an ash amorphous powder, coded, $\mathbf{G}_{2}$ (746 mg).

\subsection{Antihyperglycaemic Assay of Isolated Compounds}

The two isolated compounds, $\mathbf{G}_{\mathbf{1}}$ and $\mathbf{G}_{\mathbf{2}}$ were tested for anti-hyperglycaemic assay as described earlier.

\subsection{Statistical analysis}

The data obtained from the study were expressed as the mean \pm SEM for the number $(n=5)$ of animals in the groups. They were analysed with One Way Analysis of Variance (ANOVA), followed by Bonferroni t-test or Student-NewmanKeuls post hoc tests, using GraphPad ${ }^{\circledR}$ Instat, version 5.0 (GraphPad Software Inc., San Diego, USA). P < 0.05 was considered significant.

\subsection{Structure Elucidation of Isolated Compounds}

G1: m.p 151-152 ${ }^{\circ} \mathrm{C}$; ESI-MS (rel. int. \%): [M] ${ }^{+}$at $m / z 424.9$ (9.5 \%) consistent with the molecular formula $\mathrm{C}_{30} \mathrm{H}_{48} \mathrm{O}$, [M - $\left.0^{-}\right]^{+}$at $m / z 410.0$ (43.6\%), [M - $\left.\mathrm{C}_{23} \mathrm{H}_{29}\right]^{+}$at $\mathrm{m} / z 105.3$ (10.0\%); UV $\left(\mathrm{CHCl}_{3}\right) \boldsymbol{\lambda}_{\max }: 270.50 \mathrm{~nm}$; IR (KBr) $U_{\max } \mathrm{Cm}^{-1}: 2948.3$ (Sp; $\mathrm{C}-\mathrm{H}$ ), 2836.5 ( $\left.\mathrm{Sp}_{3} \mathrm{C}-\mathrm{H}\right), 1681.0$ (C=0 of ketone), $1325.1-1121.9$ (C - O, overtone); ${ }^{\mathbf{1}} \mathbf{H}-\mathbf{N M R}(300 \mathrm{MHz}, \mathrm{CDCl} 3)$ $\delta$ ppm: $0.75(3 \mathrm{H}, s, \mathrm{H}-25), 0.89(3 \mathrm{H}, d, J=6.0 \mathrm{~Hz}, \mathrm{H}-29), 0.98(3 \mathrm{H}, s, \mathrm{H}-26), 1.03(3 \mathrm{H}, d, J=3.0 \mathrm{~Hz}, \mathrm{H}-30), 1.07(3 \mathrm{H}, s, \mathrm{H}-24)$, $1.20(3 \mathrm{H}, s, \mathrm{H}-23), 1.28(3 \mathrm{H}, s, \mathrm{H}-28) .{ }^{13} \mathrm{C}-\mathrm{NMR}\left(75 \mathrm{MHz}, \mathrm{CDCl}_{3}\right) \delta_{\mathrm{ppm}}: 39.27(\mathrm{C}-1), 32.80(\mathrm{C}-2), 213.18(\mathrm{C}-3), 42.16$ (C-4), 59.51 (C-5), 36.03 (C-6), 22.30 (C-7), 37,47 (C-8), 58.25 (C-9), 38.32 (C-10), 35.65 (C-11), 35.36 (C-12), 28.19 (C-13), 30.02 (C-14), 30.52 (C-15), 32.46 (C-16), 39.72 (C-17), 53.12 (C-18), 42.82 (C-19), 35.04 (C-20), 41.32 (C-21), 41.54 (C22), 31.80 (C-23), 20.27 (C-24), 14.68 (C-25), 17.96 (C-26), 18.26 (C-27), 32.11 (C-28), 6.84 (C-29), 18.68 (C-30).

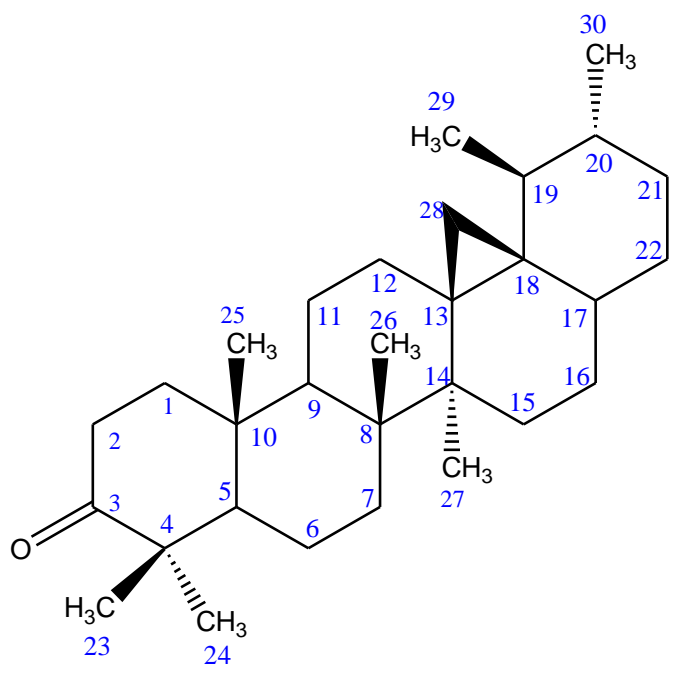

Chemical structure of (G1)

13,28-cycloursan-3-one

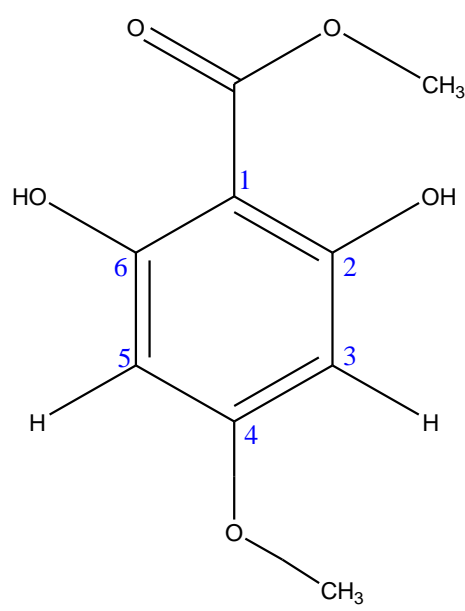

Chemical structure of (G2)

methyl 2,6-dihydroxy-4-methoxybenzoate

G2: m.p 160-161 ${ }^{\circ} \mathrm{C}$; ESI-MS (rel. int. \%): [M + 3] ${ }^{+}$at (50.8 \%) $\mathrm{m} / \mathrm{z} 198.0$ consistent with the molecular formula $\mathrm{C}_{9} \mathrm{H}_{10} \mathrm{O}_{5}$ ,loss of $-\mathrm{OCH}_{3}[\mathrm{M}-31]^{+}$at $m / z$ 167.3, [M-34] ${ }^{+}$at $m / z 154.3(13.5 \%)$, loss of methyl ethanoate $[\mathrm{M}-60]^{+}$at $m / z$ 135.2 (3.5\%), loss of both $-\mathrm{OCH}_{3}$ and methyl ethanoate substituents $\left[\mathrm{C}_{3} \mathrm{H}_{6} \mathrm{O}_{3}\right]^{+}$at $m / z 107.1[\mathrm{M}-91]^{+} ; \mathbf{U V}-\mathbf{V i s}(\mathbf{M e O H}) \lambda_{\max }$ : 
$210 \mathrm{~nm}, 232 \mathrm{~nm}, 253.0 \mathrm{~nm}$; ${ }^{1} \mathrm{H}-\mathbf{N M R}$ ( $\left.300 \mathrm{MHz}, \mathrm{MeOD}\right) \delta_{\mathrm{ppm}}: 3.85\left(3 \mathrm{H}, \mathrm{s}, \mathrm{H}-1_{\mathrm{a}}\right), 3.91(3 \mathrm{H}, d, J=3.0 \mathrm{~Hz}, \mathrm{H}-4 \mathrm{a}), 4.89(1 \mathrm{H}$, $s, \mathrm{H}-2, \mathrm{H}-6), 7.36$ (1H, s, H-3, H-5). ${ }^{13} \mathrm{C}-\mathrm{NMR}:(75 \mathrm{MHz}, \mathrm{MeOD}) \delta_{\mathrm{ppm}}$ : 55.26 (C-4a), 59.72 (C-1b), 106.80 (C-3, C-5), 125.72 (C-1), 142.41 (C-4), 152.90 (C-2, C-6), 168.05 (C-1 a).

\section{Results and discussion}

\subsection{Safety profile of $G$. braunii}

Acute toxicity studies that were carried out through oral administration of the ethanol leaf extract of $G$. braunii at 10 , $100,1,000,1,600,2,900$ and $5,000 \mathrm{mg} / \mathrm{kg}$ did not produce death in the animals used. Also, there were no significant changes in their behaviours such as breathing, cutaneous effect, sensory and nervous system responses or on gastrointestinal effects. This showed that the median lethal dose $\left(L_{50}\right)$ of the ethanol leaf extract of $G$. braunii is above $5,000 \mathrm{mg} / \mathrm{kg}$ and that the chosen doses of 100,200 and $400 \mathrm{mg} / \mathrm{kg}$ used in the evaluation of the antihyperglycaemic activity of the extract were therapeutically safe.

\subsection{Antihyperglycaemic effects of the extract}

In glucose-induced antihyperglycaemic experiments of medicinal plants or orthodox drugs involving the use of glibenclamide and other insulinotropic drugs as positive controls, it has been established that results obtained from such experiments can be extrapolated on the Type 2 diabetic state in humans [20, 21, 24]. Furthermore, the use of glibenclamide in antidiabetic experiments as the standard drug [25] could be used to determine the early extrapancreatic and late insulin stimulating effects in terms of the mechanisms of action of the extract being investigated [22, $23,26]$.

Table 1 Antihyperglycaemic effects of Globimetula braunii extract

\begin{tabular}{|c|c|c|c|c|c|}
\hline \multirow{2}{*}{$\begin{array}{l}\text { Dose of } \\
\text { extract/Drug } \\
\text { (mg/kg) }\end{array}$} & \multicolumn{5}{|c|}{$\begin{array}{l}\text { Blood glucose level as percentage of } T_{0} \text { (reduction in blood glucose relative to negative control } \\
\text { at } T_{t} \text { ) }\end{array}$} \\
\hline & $0 \mathrm{~h}$ & $0.5 \mathrm{~h}$ & $1 \mathrm{~h}$ & $2 \mathrm{~h}$ & $4 \mathrm{~h}$ \\
\hline GLU $(10 \mathrm{~g} / \mathrm{kg})$ & 100.0 & $83.79 \pm 3.8^{b}$ & $85.89 \pm 0.50^{\mathrm{b}}$ & $76.45 \pm 1.71 b$ & $74.18 \pm 1.97 c$ \\
\hline A (100) & 100.0 & $\begin{array}{l}60.84 \pm 4.80^{\mathrm{a}} \\
27.39 \%\end{array}$ & $\begin{array}{l}56.59 \pm 5.24^{\mathrm{a}} \\
34.11 \%\end{array}$ & $\begin{array}{l}47.70 \pm 3.26^{\mathrm{a}} \\
37.61 \%\end{array}$ & $\begin{array}{l}40.24 \pm 5.11^{\mathrm{a}} \\
45.75 \%\end{array}$ \\
\hline $\mathbf{A}(200)$ & 100.0 & $\begin{array}{l}83.06 \pm 4.82^{\mathrm{b}} \\
0.87 \%\end{array}$ & $\begin{array}{l}75.52 \pm 5.16^{\mathrm{b}} \\
12.07 \%\end{array}$ & $\begin{array}{l}70.35 \pm 5.59^{b} \\
7.98 \%\end{array}$ & $\begin{array}{l}63.83 \pm 6.28^{\mathrm{b}, \mathrm{c}} \\
13.95 \%\end{array}$ \\
\hline A (400) & 100.0 & $\begin{array}{l}93.01 \pm 3.77 b \\
-11.0 \%\end{array}$ & $\begin{array}{l}87.62 \pm 3.42^{b} \\
-2.01 \%\end{array}$ & $\begin{array}{l}68.06 \pm 3.04^{b} \\
10.97 \%\end{array}$ & $\begin{array}{l}63.44 \pm 1.89 \mathrm{~b}, \mathrm{c} \\
14.47 \%\end{array}$ \\
\hline GLI (5) & 100 & $\begin{array}{l}75.60 \pm 6.70^{\mathrm{a}, \mathrm{b}} \\
9.77 \%\end{array}$ & $\begin{array}{l}70.70 \pm 6.90^{\mathrm{a}, \mathrm{b}} \\
17.69 \%\end{array}$ & $\begin{array}{l}58.30 \pm 6.40^{\mathrm{a}, \mathrm{b}} \\
23.74 \%\end{array}$ & $\begin{array}{l}45.30 \pm 6.90^{\mathrm{a}, \mathrm{b}} \\
38.93 \%\end{array}$ \\
\hline
\end{tabular}

Data show the mean \pm SEM blood glucose levels at the different time points expressed as percentages of levels at $0 \mathrm{~h}$ $\left(\mathrm{T}_{0}\right), n=5$. Values in parentheses represent the percentage reductions in blood glucose levels relative to negative control for each time point. Values with different superscripts within columns are significantly different $(p<0.05)$. GLU: Glucose in $<1 \%$ of Tween 80 in normal saline administered at $10 \mathrm{~g} / \mathrm{kg}$ (hyperglycaemic negative control); A: Globimetula braunii extract; GLI: Glibenclamide ( $5 \mathrm{mg} / \mathrm{kg}$, positive control).

A significant $(\mathrm{p}<0.05)$ time-dependent hyperglycaemia-lowering effects up to the fourth hour was observed in the negative control group of rats that were given normal saline. This activity could be attributed to the normal homeostatic regulatory mechanism in normal animals which confirmed the healthy state of the pancreases of the animals used in the study [20-23]. Also, the positive control group of rats that were administered with glibenclamide $(5 \mathrm{mg} / \mathrm{kg})$ gave a significant time-dependent antihyperglycaemic activity up to fourth hour (Table 1). This observation confirmed the early minor extra pancreatic and late major insulin releasing (insulinotropic) mechanisms of action of glibenclamide [25]. The extract of $G$. braunii at $100 \mathrm{mg} / \mathrm{kg}$ elicited a time-dependent glucose lowering activity up to the fourth hour 
that was significantly higher $(\mathrm{p}<0.05)$ than the 200 and $400 \mathrm{mg} / \mathrm{kg}$ doses indicating a non-dose dependent activity of the extract (Table 1). Also, the extract at this dose gave similar profile ofactivity at $0.5-4 \mathrm{~h}$ to glibenclamide $(5 \mathrm{mg} / \mathrm{kg})$ which suggested that the extract had similar early extra pancreatic and late major insulin stimulating mechanisms ofaction with glibenclamide at this dose [25]. The high blood glucose level reductions of 27, 34 and $38 \%$ elicited by 100 $\mathrm{mg} / \mathrm{kg}$ of the extract at $0.5-2 \mathrm{~h}$ further suggested additional extrapancreatic effect of the extract at this dose (Table 1). The ethanol leaf extract of $G$. braunii had previously been reported to show hypoglycaemic effect in alloxan-induced diabetic rats at 250 and $500 \mathrm{mg} / \mathrm{kg}$ after 2 and $4 \mathrm{~h}$ [27]. This result further supported insulin stimulation as the main mechanism of action of $G$. braunii leaf extract that was suggested by the results of this present work (Table 1). The extracts of Carica papaya, Xylopia aethiopica, Parquetina nigrescens, Chrysophylum albidum, Senecio biafrae have similarly been suggested to work through insulin stimulation [28-32].

\subsection{Antihyperglycaemic Activity of Partition Fractions of $G$. braunii Extract}

Table 2 Antihyperglycaemic effects of partition fractions (100 mg/kg) of Globimetula braunii ethanol extract

\begin{tabular}{|c|c|c|c|c|c|}
\hline \multirow{2}{*}{$\begin{array}{l}\text { Doses of } \\
\text { extract/Drug(mg } \\
\text { /kg) }\end{array}$} & \multicolumn{5}{|c|}{$\begin{array}{l}\text { Blood glucose level as percentage of } T_{0} \text { (reduction in blood glucose relative to negative } \\
\text { control at } T_{t} \text { ) }\end{array}$} \\
\hline & $\mathbf{0 ~ h}$ & $0.5 \mathrm{~h}$ & $1 \mathrm{~h}$ & $2 \mathrm{~h}$ & $4 h$ \\
\hline GLU(10 g/kg) & 100.0 & $83.79 \pm 3.8^{b}$ & $85.89 \pm 0.50^{\mathrm{b}}$ & $76.45 \pm 1.71^{\mathrm{b}}$ & $74.18 \pm 1.97^{c}$ \\
\hline \multirow[t]{2}{*}{ A (100) } & 100.0 & $60.84 \pm 4.80^{\mathrm{a}}$ & $56.59 \pm 5.24^{\mathrm{a}}$ & $47.70 \pm 3.26^{a}$ & $40.24 \pm 5.11^{\mathrm{a}}$ \\
\hline & & $27.39 \%$ & $34.11 \%$ & $37.61 \%$ & $45.75 \%$ \\
\hline \multirow[t]{2}{*}{$\mathrm{B}_{1}(100)$} & 100.0 & $79.04 \pm 3.59^{\mathrm{a}, \mathrm{b}}$ & $68.30 \pm 5.85^{\mathrm{a}, \mathrm{b}}$ & $59.87 \pm 4.45^{\mathrm{a}, \mathrm{b}}$ & $44.79 \pm 3.56^{\mathrm{a}, \mathrm{b}}$ \\
\hline & & $5.67 \%$ & $20.48 \%$ & $21.69 \%$ & $39.62 \%$ \\
\hline \multirow[t]{2}{*}{$\mathrm{B}_{2}(100)$} & 100.0 & $83.76 \pm 6.24^{b}$ & $83.55 \pm 6.23^{b}$ & $82.01 \pm 6.27^{b}$ & $51.51 \pm 4.7^{\mathrm{a}, \mathrm{b}}$ \\
\hline & & $0.04 \%$ & $2.73 \%$ & $7.27 \%$ & $30.56 \%$ \\
\hline \multirow[t]{2}{*}{$\mathrm{B}_{3}(100)$} & 100.0 & $86.23 \pm 10.62^{b}$ & $95.34 \pm 14.48^{b}$ & $79.58 \pm 8.09 \mathrm{~b}$ & $65.78 \pm 7.54^{\mathrm{b}, \mathrm{c}}$ \\
\hline & & $-2.91 \%$ & $-11.00 \%$ & $-4.09 \%$ & $11.32 \%$ \\
\hline \multirow[t]{2}{*}{$\mathrm{B}_{4}(100)$} & 100.0 & $69.19 \pm 3.86^{\mathrm{a}, \mathrm{b}}$ & $65.29 \pm 4.72^{\mathrm{a}, \mathrm{b}}$ & $57.11 \pm 4.40^{a}$ & $40.55 \pm 4.19 a$ \\
\hline & & $17.43 \%$ & $23.98 \%$ & $25.3 \%$ & $45.34 \%$ \\
\hline \multirow[t]{2}{*}{ GLI (5) } & 100.0 & $75.60 \pm 6.70^{\mathrm{a}, \mathrm{b}}$ & $70.70 \pm 6.90^{\mathrm{b}}$ & $58.30 \pm 6.40^{\mathrm{a}, \mathrm{b}}$ & $45.30 \pm 6.90^{\mathrm{a}, \mathrm{b}}$ \\
\hline & & $9.77 \%$ & $17.69 \%$ & $23.74 \%$ & $38.93 \%$ \\
\hline
\end{tabular}

Data show the mean \pm SEM blood glucose levels at the different time points expressed as percentages of levels at $0 \mathrm{~h}$ $\left(\mathrm{T}_{0}\right), n=5$. Values in parentheses represent the percentage reductions in blood glucose levels relative to negative control for each time point. Values with different superscripts within columns are significantly different $(p<0.05)$.GLU: Glucose in $<1 \%$ of Tween 80 in normal saline administered at $10 \mathrm{~g} / \mathrm{kg}$ (hyperglycaemic negative control); A: Globimetula braunii extract; $\mathbf{B}_{\mathbf{1}}=$ dichloromethane fraction; $\mathbf{B}_{2}=$ Ethylacetate fraction; $\mathbf{B}_{\mathbf{3}}=$ Butanol fraction; $\mathbf{B}_{\mathbf{4}}=$ Aqueous fraction; $\mathbf{G L I}$ : Glibenclamide (5 $\mathrm{mg} / \mathrm{kg}$, positive control).

Based on the results of the antihyperglycaemic effects of $G$. braunii ethanol leaf extract (Table 1), the active extract was subjected to solvent partitioning and the resulting partitioned fractions of the extract were tested for

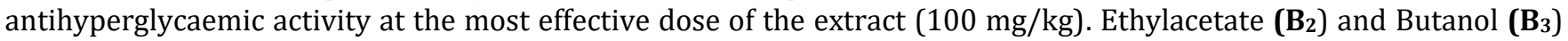
fractions were devoid of antihyperglycaemic activity at $0.5-2 \mathrm{~h}$ but gave 31 and $11 \%$ blood glucose levels reduction at $4 \mathrm{~h}$, respectively which indicated that they lacked extrapancreatic activity but had insulin stimulating effect with $\mathbf{B}_{2}$ showing higher activity (Table 2). Fractions $\mathbf{B}_{\mathbf{1}}$ and $\mathbf{B}_{\mathbf{4}}$ gave comparable $(\mathrm{p}>0.05)$ and time-dependent activity at alltime points that were similar in profile to glibenclamide which suggested early extrapancreatic and late insulin stimulation mechanism of action [25]. It also indicated that the antihyperglycaemic constituents of the extract were more concentrated in $\mathbf{B}_{\mathbf{1}}$ and $\mathbf{B}_{\mathbf{4}}$ which were non polar and very polar in nature, respectively. Furthermore, none of the partitioned fractions, $\mathbf{B}_{\mathbf{1}}-\mathbf{B}_{\mathbf{4}}$ was significantly more active than the extract indicating that the antihyperglycaemic constituents of $\mathbf{A}$ were working in synergism (Table 2).

\subsection{Antihyperglycaemic activity of the bulked column fractions of $G$. braunii}


Ayoola et al. / GSC Biological and Pharmaceutical Sciences, 2020, 11(01), 046-054

Table 3 Antihyperglycaemic effects of bulked column $\mathbf{C}_{\mathbf{1}}-\mathbf{C}_{4}$ fractions (100 mg/kg) of Globimetula braunii extract

\begin{tabular}{|c|c|c|c|c|c|}
\hline \multirow{2}{*}{$\begin{array}{l}\text { Dose of } \\
\text { extract/Drug } \\
(\mathrm{mg} / \mathrm{kg})\end{array}$} & \multicolumn{5}{|c|}{$\begin{array}{l}\text { Blood glucose level as percentage of } T_{0} \text { (reduction in blood glucose relative to } \\
\text { negative control at } T_{t} \text { ) }\end{array}$} \\
\hline & $\mathbf{0 ~ h}$ & $0.5 \mathrm{~h}$ & $1 \mathrm{~h}$ & $2 \mathrm{~h}$ & $4 \mathrm{~h}$ \\
\hline GLU $(10 \mathrm{~g} / \mathrm{kg})$ & 100.0 & $83.79 \pm 3.8^{b}$ & $85.89 \pm 0.50^{\mathrm{b}}$ & $76.45 \pm 1.71^{\mathrm{c}}$ & $74.18 \pm 1.97 \mathrm{~b}$ \\
\hline $\mathrm{A}(100)$ & 100.0 & $\begin{array}{l}60.84 \pm 4.80^{\mathrm{a}} \\
27.39 \%\end{array}$ & $\begin{array}{l}56.59 \pm 5.24^{\mathrm{a}} \\
34.11 \%\end{array}$ & $\begin{array}{l}47.70 \pm 3.26^{\mathrm{a}} \\
37.61 \%\end{array}$ & $\begin{array}{l}40.24 \pm 5.11^{\mathrm{a}} \\
45.75 \%\end{array}$ \\
\hline $\mathrm{B}_{1}(100)$ & 100.0 & $\begin{array}{l}69.19 \pm 3.86^{\mathrm{a}, \mathrm{b}} \\
17.43 \%\end{array}$ & $\begin{array}{l}65.29 \pm 4.72^{\mathrm{a}, \mathrm{b}} \\
23.98 \%\end{array}$ & $\begin{array}{l}57.11 \pm 4.40^{\mathrm{a}, \mathrm{b}} \\
25.3 \%\end{array}$ & $\begin{array}{l}40.55 \pm 4.19^{a} \\
45.34 \%\end{array}$ \\
\hline$C_{1}(100)$ & 100.0 & $\begin{array}{l}74.03 \pm 6.72^{\mathrm{a}, \mathrm{b}} \\
11.65 \%\end{array}$ & $\begin{array}{l}56.67 \pm 6.69^{a} \\
34.02 \%\end{array}$ & $\begin{array}{l}54.82 \pm 6.11^{a, b} \\
28.29 \%\end{array}$ & $\begin{array}{l}41.18 \pm 5.51^{\mathrm{a}} \\
44.49 \%\end{array}$ \\
\hline$C_{2}(100)$ & 100.0 & $\begin{array}{l}81.34 \pm 7.06^{\mathrm{b}} \\
2.92 \%\end{array}$ & $\begin{array}{l}60.21 \pm 4.34^{\mathrm{a}} \\
29.90 \%\end{array}$ & $\begin{array}{l}54.40 \pm 7.75^{\mathrm{a}, \mathrm{b}} \\
28.84 \%\end{array}$ & $\begin{array}{l}37.83 \pm 2.72^{\mathrm{a}} \\
49.00 \%\end{array}$ \\
\hline $\mathrm{C}_{3}(100)$ & 100.0 & $\begin{array}{l}83.35 \pm 6.47 \mathrm{~b} \\
0.53 \%\end{array}$ & $\begin{array}{l}69.86 \pm 8.85 \mathrm{a}, \mathrm{b} \\
18.66 \%\end{array}$ & $\begin{array}{l}61.96 \pm 4.06^{b} \\
18.95 \%\end{array}$ & $\begin{array}{l}49.26 \pm 6.72^{\mathrm{a}} \\
33.59 \%\end{array}$ \\
\hline$C_{4}(100)$ & 100.0 & $\begin{array}{l}82.89 \pm 3.26^{\mathrm{b}} \\
1.07 \%\end{array}$ & $\begin{array}{l}72.59 \pm 7.84^{\mathrm{a}, \mathrm{b}} \\
15.48 \%\end{array}$ & $\begin{array}{l}56.44 \pm 8.51^{\mathrm{a}, \mathrm{b}} \\
26.17 \%\end{array}$ & $\begin{array}{l}44.51 \pm 4.71^{\mathrm{a}} \\
39.99 \%\end{array}$ \\
\hline GLI (5) & 100.0 & $\begin{array}{l}75.60 \pm 6.70^{a, b} \\
9.77 \%\end{array}$ & $\begin{array}{l}70.70 \pm 6.90^{\mathrm{a}, \mathrm{b}} \\
17.69 \%\end{array}$ & $\begin{array}{l}58.30 \pm 6.40^{\mathrm{a}, \mathrm{b}} \\
23.74 \%\end{array}$ & $\begin{array}{l}45.30 \pm 6.90^{\mathrm{a}} \\
38.93 \%\end{array}$ \\
\hline
\end{tabular}

Data show the mean \pm SEM blood glucose levels at the different time points expressed as percentages of levels at $0 \mathrm{~h}$ $\left(\mathrm{T}_{0}\right), n=5$. Values in parentheses represent the percentage reductions in blood glucose levels relative to negative control for each time point. Values with different superscripts within columns are significantly different $(p<0.05)$. GLU (10 $\mathrm{g} / \mathrm{kg}$ ): Glucose in $<1 \%$ of Tween 80 in normal saline administered at $10 \mathrm{~g} / \mathrm{kg}$ (hyperglycaemic negative control); A: Globimetula braunii extract; $\mathbf{B}_{1}$ : Dichloromethane fraction of Globimetula braunii extract; $\mathbf{C}_{\mathbf{1}}-\mathbf{C}_{\mathbf{4}}$ : bulked column fractions of dichloromethane fraction of Globimetula braunii extract; GLI ( $5 \mathrm{mg} / \mathrm{kg}$ ): Glibenclamide ( $5 \mathrm{mg} / \mathrm{kg}$, positive control).

Active $\mathbf{B}_{1}$ was subjected to column chromatography as described above and it afforded four bulked column fractions, $\mathbf{C}_{\mathbf{1}}-\mathbf{C}_{4}$ that were thereafter tested for antihyperglycaemic activity at $100 \mathrm{mg} / \mathrm{kg}$ (the most effective dose of the extract). The findings showed that $\mathbf{C}_{1}-\mathbf{C}_{4}$ elicited comparable $(p>0.05)$ blood glucose level reduction effect with glibenclamide at $4 \mathrm{~h}$ suggesting insulin release as their major mechanism of action (Table 3). While $\mathbf{C}_{\mathbf{1}}$ and $\mathbf{C}_{\mathbf{2}}$ gave a non time-dependent antihyperglycaemic effect, the activity of $\mathbf{C}_{3}$ and $\mathbf{C}_{\mathbf{4}}$ were time dependent. The additional extrapancreatic effect that was observed in the extract was found in $\mathbf{C}_{\mathbf{1}}$ and $\mathbf{C}_{2}$. This showed that chromatographic purification of the extract in this work has successfully separated the extrapancreatic constituents. Furthermore; $\mathbf{C}_{\mathbf{1}}-\mathbf{C}_{\mathbf{4}}$ gave comparable effect both to $\mathbf{B}_{\mathbf{1}}$ and the $\mathbf{A}$ at $4 \mathrm{~h}$ which showed synergism in the antihyperglycaemic constituents of the bulked column fractions (Table 3).

\subsection{Antihyperglycaemic effects of the isolated compounds from $G$. braunii}

Isolated compound $\mathbf{G}_{1}$, phyllanthone demonstrated a time-dependent and comparable antihyperglycaemic activity at 10 and $20 \mathrm{mg} / \mathrm{kg}$ suggesting insulin release as its major mechanism of action and that its activity was not dose dependent (Fig.1). However, the activity of $\mathbf{G}_{2}$,methyl 2, 6-dihydroxy-4-methoxybenzoate was not time-dependent while the $10 \mathrm{mg} / \mathrm{kg}$ dose gave a significantly better blood glucose lowering effect than the $20 \mathrm{mg} / \mathrm{kg}$ at $4 \mathrm{~h}$. Both phyllanthone, and methyl 2, 6-dihydroxy-4-methoxybenzoate demonstrated comparable and similar profile of antihyperglycaemic effects to glibenclamide which suggested minor extrapancreatic and major insulin stimulating mechanism of action for the compounds [21-24]. These results thereforeidentified phyllanthone, and methyl 2,6dihydroxy-4-methoxybenzoate as two of the antihyperglycaemic constituents of Globimetula braunni. 
Ayoola et al. / GSC Biological and Pharmaceutical Sciences, 2020, 11(01), 046-054

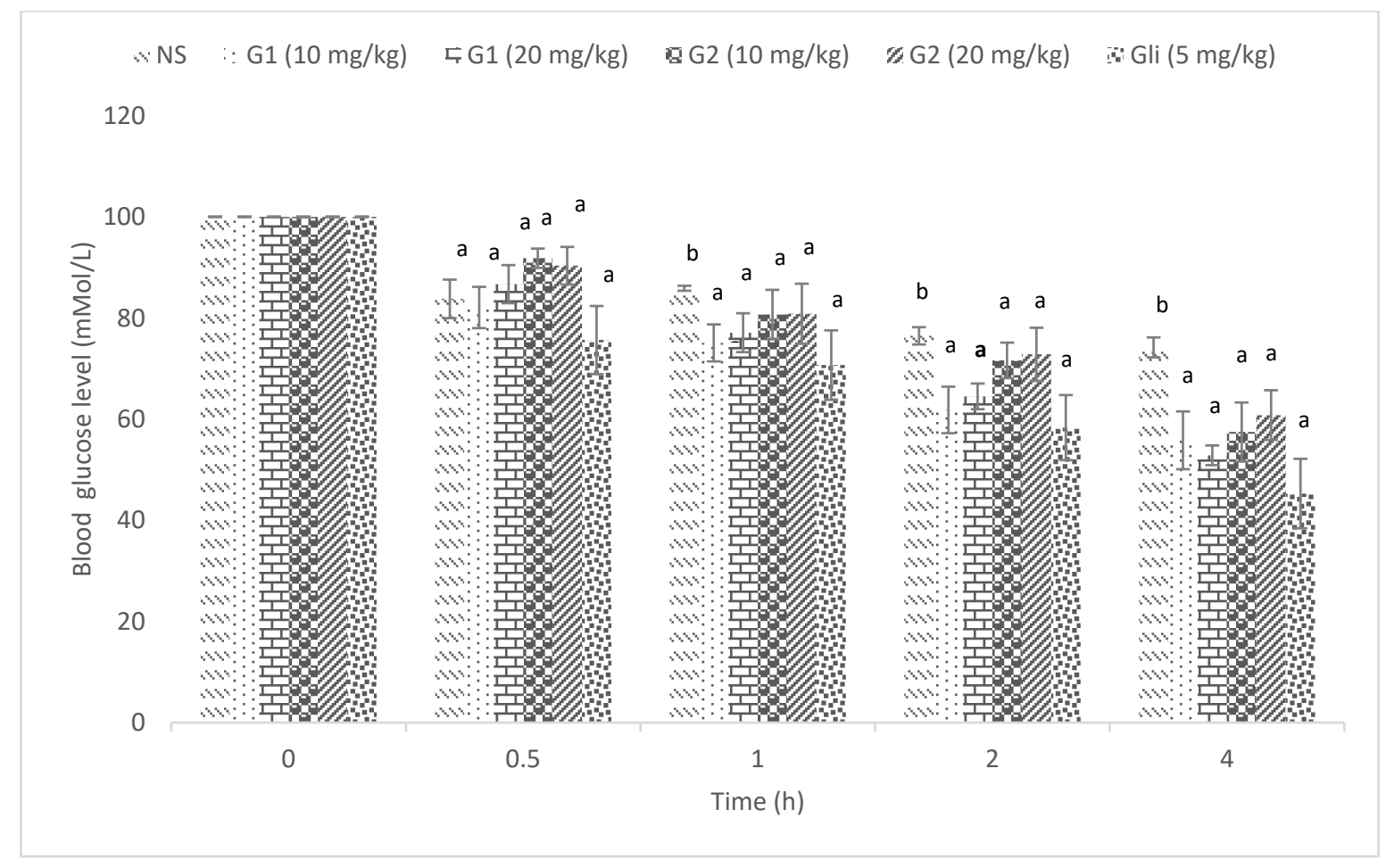

Figure 1 Antihyperglycaemic effects of the isolated compounds from Globimetula braunii

Data show the mean \pm SEM blood glucose levels at the different time points expressed as percentages of levels at $0 \mathrm{~h}\left(\mathrm{~T}_{0}\right), n$ $=5$. Values in parentheses represent the percentage reductions in blood glucose levels relative to negative control for each time point. Values with different superscripts within columns are significantly different $(p<0.05)$. NS: Glucose in $<1 \%$ of Tween 80 in normal saline; $\mathbf{G}_{1}$ : phyllanthone; $\mathbf{G}_{2}$ : methyl 2, 6-dihydroxy-4-methoxybenzoate; Gli: Glibenclamide $(5 \mathrm{mg} / \mathrm{kg})$.

The spectra data of the isolated compounds, $\mathbf{G}_{\mathbf{1}}$ and $\mathbf{G}_{\mathbf{2}}$ were compared with those from the literature. Compound $\mathbf{G}_{\mathbf{1}}$ has been characterized as a 13, 27-cycloursan-3-one reported from the stem bark of Phyllanthus polyanthus as "phyllanthone" [33]. Also $\mathbf{G}_{2}$ was characterized as methyl 2, 6-dihydroxy-4-methoxybenzoate [34]. The two compounds were isolated for the first time from the leaf of Globimetula braunii and reported in this work.

\section{Conclusion}

Lack of death in the animals when administered with high dose of the ethanol leaf extract of $G$. braunii in acute toxicity study confirmed its safety. Also the antihyperglycaemic activity of the extract at the lowest tested dose, $100 \mathrm{mg} / \mathrm{kg}$ indicated its efficacy while phyllanthone and methyl 2, 6-dihydroxy-4-methoxybenzoate with comparable antihyperglycaemic effect to glibenclamide were two of its active constituents. These results justified the antidiabetic ethno-medicinal use of the plant.

\section{Compliance with ethical standards}

\section{Acknowledgments}

The authors appreciated Professors Gilbert Arthur and Frank Schweizer of the University of Manitoba, Canada for making their Spectroscopic research laboratory available for the study. The effort of Mr. I.I. Ogunlowo in collecting the plant was also recognized.

\section{Disclosure of conflict of interest}

The authors declared that there is no conflict of interest with regard to this work. 


\section{Statement of ethical approval}

All animal experiments in this study conformed to the Guide for the Care and Use of Laboratory Animals published by the National Academies Press.

\section{References}

[1] Sofowora A. (2008). Medicinal plants and traditional medicine in Africa, 3rd edition, Spectrum Books Ltd, Ibadan, 7.

[2] Lai PK and Roy J. (2004). Antimicrobial and chemopreventive properties of herbs and spices. Curr. Med. Chem, 11(11), 1451-60.

[3] Tan AC, Konczak I, Sze DM and Ramzan I. (2010). Towards the discovery of novel phytochemicals for disease prevention from native Australian plants: an ethnobotanical approach. Asian Pacific Journal Clinical Nutrition, 19(3), 330-334.

[4] Tapsell LC, Hemphill I, Cobiac L, Patch CS, Sullivan DR, Fenech M, Roodenrys S, Keogh JB, Clifton PM, Williams PG, Fazio VA and Inge KE. (2006). Health benefits of herbs and spices: the past, the present, the future. Medicinal Journal of Australia, 185(4), S4-24.

[5] Rates SMK. (2001). Plants as source of drugs. Toxicon, 39(5), 603-13.

[6] Gurib-Fakim A. (2006). Medicinal plants: Traditions of yesterday drugs of tomorrow. Mol. Asp. Med, 27(1), 1-93.

[7] Tizhe TD, Alonge SO and Aliyu RE. (2015). Antibacterial Activity of Globimetula braunii Sourced from Five Different Host Trees in Samaru, Zaria, Nigeria. Int. J. Curr. Sci, 18, 117-23.

[8] Burkill HM. (1985).The Useful Plants of West Tropical Africa, vol. 3, 2nd edn, Royal Botanic Gardens, Kew. ISBN 094764301X.

[9] Okpuzor J, Kareem G andEjikeme C. (2009a). Lipid Lowering Activity of Globimetula braunii. Research Journal of Medicinal Plant, 3(2), 45-51.

[10] Okpuzor J, Ogbunugafor H and Kareem GK. (2009). Hepatic and hematologic effects of fractions of Globimetula braunii in normal albino rats. Excli Journal, 8(1), 182-189.

[11] Okpuzor J, Ogbunugafor H and Kareem GK. (2009). Antioxidative Properties of Ethyl Acetate Fraction of Globimetula braunii in Normal Albino Rats. Journal of Biological Sciences, 9(5), 470-3.

[12] Fred-Jaiyesimi A, Onabanjo T andJaiyesimi A. (2008). Biochemical and Toxicological Effects of Globimetula braunii (Loranthaceae) Leaf. African Journal of Traditional Complementary and Alternative Medicine, 6(2), 1115.

[13] Oboh IE andNworgu ZAM. (2008). Oxytocic properties of the aqueous extract of Globimetula braunii (Loranthaceae). Pak. J. Pharm. Sci., 21, 356-60.

[14] Olagunju JA. (1999). Thehypoglycaemic property of normal saline leaf extract of Globimetula braunii in alloxanized diabetic albino rats. Biomed Lett., 60(235), 83-9.

[15] Aliyu MM, Musa AII, Kamal MJA and Mohammed MG. (2014). Phytochemical screening and anticonvulsant studies of ethyl acetate fraction of Globimetula braunii on laboratory animals. Asian Pacific Journal of Tropical Biomedicine, 4(4), 285-289.

[16] Atiku I, Sule MI, Pateh UU, Musa AM, Ya'u J, Sani YM, Hanwa UA, Abdullahi SM, Adamu SA, Lawal EA and Abdulrahman H. (2015). Phytochemical, Anti-inflammatory and Analgesic Studies of the Crude Ethanolic Leaf Extract of Globimetula braunii Van Tiegh (Loranthaceae). Natural Products Chemistry and Research, 3(6), 1- 4.

[17] Ja'afar MK, Jamil S, Basar N, Bakar MB, Sarker SD, Flanagan K and Senge M. (2017). Lactones and Flavonoids isolated from the Leaves of Globimetula braunii. Natural Product Communications, 12(9), 1455-1458.

[18] Committee for the update of the guide for the care and use of laboratory animals, institute for laboratory animal research, division on earth and life studies, national research council of the national academies (2011). Guide for the Care and Use of Laboratory Animals, 8th ed. The National Academies Press, Washington, DC.

[19] Lorke D. (1983). A new approach to practical acute toxicity testing. Arch. Toxicol., 54(4), 275-87. 
[20] Adebajo AC, Ayoola MD, Obagbemi OR, Obuotor EM, Ogunsina MO andVerspohl EJ. (2013). Antihyperglycaemic and antioxidant activities of Eugenia uniflora leaf: evaluation of ethnomedical claims IV Ife Journal of Science and Technology, 1, 1-18.

[21] Adebajo AC, Ayoola MD, Odediran SA, Aladesanmi AJ, Schmidt TJ andVerspohl EJ. (2013). Evaluation of ethnomedical claims III: anti-hyperglycaemic activities of Gongronema latifolium root and stem. Journal of Diabetes, 5, 336-43.

[22] Ayoola MD, Akinwunmi KF and Agboola OB. (2017). Anti-diabetic and Antioxidant Activities of Entandrophragma cylindricum and Triclisia subcordata. Nigerian Journal of Natural Products and Medicine, 21, 24-31.

[23] Ayoola MD, Adebajo AC, Obuotor EM, Oladapo TO and Fleischer TC. (2017). Anti-hyperglycaemic and anti-oxidant activities of five Nigerian antidiabetic plants. Journal of Science and Technology KNUST, 37(2), 71-84.

[24] Verspohl EJ. (2002). Recommended testing in diabetes research. Planta Medica, 68, 581-90.

[25] Luzi L and Pozza G. (1997). Glibenclamide: an old drug with a novel mechanism of action? ActaDiabetologica, 34, 239-44.

[26] Murray RK, Granner DK and Rodwell VW. (2006). Harper's Illustrated Biochemistry. 27th Ed., International Edition, McGraw-Hill Education (Asia), Singapore, 172-5.

[27] Okpanachi GO, Oyi AR, Musa H, Abdulsamad A, Sani MB and Ya'u J. (2018). Phytochemical Screening and Hypoglycaemic Property of Globimetula braunii (Loranthaceae) Leaf Extracts. Journal of Pharmaceutical Research International, 22(1), 1-11.

[28] Akinwunmi KF and Ayoola MD. (2018). Antihyperglycaemic, anti-inflammatory and antioxidant activities of Carica papaya and Citrus lanatus seeds. Ife J. Sci., 20(2), 207-217.

[29] Famuyiwa FG, Ayoola MD., Famuyiwa SO and Aladesanmi AJ. (2018). Hyperglycaemia Lowering Effect of Kaurane Diterpenoids from the Fruits of Xylopia aethiopica (A. Dunal) Rich. International Journal of Medicinal Plants and Natural Products, 4(3), 11-19.

[30] Faloye KO, AyoolaMD, Amos-TautuaBM and Famuyiwa SO. (2018). Anti-diabetic Activity of Convallatoxin Isolated from the Root Bark of Parquetina nigrescens (Afzel.) Bullock (Asclepiadaceae). European Journal of Medicinal Plants, 25(4), 1-9.

[31] Olanudun EA, Ayoola MD and Famuyiwa SO. (2018). The isolation and characterisation of lupeol-3-acetate from the hyperglycaemia-lowering fraction of the stem bark of Chrysophyllum albidum. Ife Journal of Science, 20(2), 229-236.

[32] Ayoola MD, Adebajo CA, Zotor FB and Pinkoane MG. (2019). Justifying Antidiabetic Ethnomedicinal Claim of Senecio biafrae through its Antihyperglycaemic and Antioxidant Activities. Annals of Complementary and Alternative Medicine, 1(2), 1-8.

[33] Ndlebe VJ, Crouch NR and Mulholland DA. (2008). Triterpenoids from the African tree Phyllanthus polyanthus. Phytochemistry Letters, 1, 11-7.

[34] Tjahjandarie, TS, Saputri RD and Tanjung M. (2016). Methyl 2,5-Dihydroxy-4-(31-methyl-21-butenyl) benzoate. Molbank M892.

\section{How to cite this article}

Ayoola MD, Oriola AO, Faloye KO and Aladesanmi AJ. (2020). Two antihyperglycaemic compounds from Globimetula braunii (Engl.) Van Tiegh (Loranthaceae). GSC Biological and Pharmaceutical Sciences, 11(1), 46-54. 